\title{
PENERAPAN TEKNIK KLASIFIKASI DALAM SISTEM PENDUKUNG KEPUTUSAN PENERIMAAN RASKIN MENGGUNAKAN METODE FUZZY TOPSIS
}

\author{
Fitri Ayu Ramadhani \\ Sistem Informasi, STMIK Bina Nusantara Jaya Lubuklinggau \\ Jalan Yos Sudarso No 97 A Kota Lubuklinggau Sumatera Selatan \\ E-mail : fitriayuramadhani97@gmail.com
}

\begin{abstract}
Food aid distribution began in 2017 in 44 cities that have adequate access and facilities. Gradually, food aid will be extended to all cities and districts by the preparation of facilities and infrastructure for the distribution of aid. Raskin's one of the staple food subsidy programs in the form of rice aimed at poor families carried out by the government in improving food security. Raskin recipient families are poor families (vulnerable and vulnerable to poverty) or referred to as Target Household. This program aims to reduce the burden on Target Households by meeting some basic needs in the form of rice. Fuzzy is an input space that becomes an output space consisting of several possibilities, different from digital or Boolean logic which has only two possibilities, whereas topsis is one method that is quite accurate because it not only takes into account the maximum ideal distance but also looking for the minimum ideal distance. In ponorogo village, data collection was not yet effective, because the submission process for eligibility for Raskin recipients was not by the criteria. For this reason, a system is needed to assist village officials in the process of accepting the eligibility of Raskin recipients.
\end{abstract}

Keywords: Decision Support System, Fuzzy Topsis, Raskin Election Determination

\begin{abstract}
Abstrak
Penyaluran bantuan pangan mulai dilaksanakan pada tahun 2017 di 44 kota yang memliki akses dan fasilitas memadai. Secara bertahap, bantuan pangan akan diperluas ke seluruh kota dan kebupaten sesuai dengan persiapan sarana dan prasarana penyaluran bantuan tersebut. Raskin merupakan salah satu program subsidi pangan pokok dalam bentuk beras yang diperuntukkan untuk keluarga miskin sebagai upaya yang dilakukan pemerintah dalam meningkatkan ketahanan pangan. Keluarga penerima Raskin adalah keluaraga yang berpendapatan rendah (miskin dan rentan miskin) atau disebut dengan Rumah Tangga Sasaran (RTS). Program ini bertujuan untuk mengurangi beban pengeluaran Rumah Tangga Sasaran (RTS) melalui pemenuhan sebagian kebutuhan pokok dalam bentuk beras (Ombi Romli,2017). Fuzzy merupakan sebuah ruang input yang menjadi sebuah ruang output yang terdiri dari beberapa kemungkinan, berbeda dengan logika digital atau Boolean yang hanya memiliki dua kemungkinan saja, sedangkan topsis merupakan salah satu metode yang cukup akurat, karena tidak hanya memperhitungkan mengenai jarak ideal maksimum, namun juga mencari jarak ideal minimum. Pada kelurahan ponorogo saat pendataan belum efektif, karena pada kenyataannya proses pendataan kelayakan penerima raskin tidak berdasarkan pada kriteria yang ada. Untuk itu, dibutuhkannya sebuah sistem yang dapat membantu petugas kelurahan dalam hal proses penentuan kelayakan penerima raskin
\end{abstract}

Kata kunci: Sistem Pendukung Keputusan, Fuzzy Topsis, Penentuan Pemilihan Raskin

\section{Pendahuluan}

Penyaluran bantuan pangan mulai dilaksanakan pada tahun 2017 di 44 kota yang memliki akses dan fasilitas memadai. Secara bertahap, bantuan pangan akan diperluas ke seluruh kota dan kebupaten sesuai dengan persiapan sarana dan prasarana penyaluran bantuan tersebut. Mulai tahun 2018, program raskin yang saat ini telah berganti nama dengan rasta, subsidi rasta juga diahlikan menjadi bantuan sosial. Dengan demikian, mulai tahun 2018 bantuan pangan akan disalurankan ke masing-masing Kabupaten/Kota dalam bentuk non tunai atau natura, yaitu tetap dalam bentuk beras [1]

Raskin merupakan salah satu program subsidi pangan pokok dalam bentuk beras yang diperuntukkan untuk keluarga miskin sebagai upaya yang dilakukan pemerintah dalam meningkatkan ketahanan pangan. Keluarga penerima Raskin adalah keluaraga yang berpendapatan rendah (miskin dan rentan miskin) atau disebut dengan Rumah Tangga Sasaran (RTS). Program ini bertujuan untuk mengurangi beban pengeluaran Rumah Tangga Sasaran (RTS) melalui pemenuhan sebagian kebutuhan pokok dalam bentuk beras.[2]

Dalam hal penyaluran raskin yang ada di kelurahan ponorogo masih dirasa kurang efektif, karena pada proses pendataan masih kurang mampu untuk menentukan kelayakan penerimaan raskin, sehingga sering kali tidak sesuai dengan data dilapangan, serta data penerima yang menerima raskin masih dicatat di dalam buku catatan. Pada praktek lapangannya, pengambilan keputusan untuk menentukan kriteria penerima beras yang biasanya sudah terjadi tidak mengacu pada kriteria-kriteria keluarga miskin, hal itu akan mengakibatkan pembagian beras miskin salah sasaran 
Metode yang dilakukan di setiap desa dalam beberapa kemungkinan, berbeda dengan logika digital pengambilan keputusan penerima beras untuk keluarga atau Boolean yang hanya memiliki dua kemungkinan miskin (Raskin) masih menggunakan cara manual yang saja[6].

databasenya masih dalam bentuk kertas dan catatan,

Konsep yang dimiliki oleh metode ini sehingga membutuhkan waktu yang lama untuk merupakan konsep yang mana alternatif yang terpilih pengolahan dan kendala yang sering terjadi adalah tidak hanya memiliki jarak terkeil dari solusi ideal yang kesulitan dalam penyimpanan atau pencarian arsip yang didapatkan, akan tetapi juga memiliki jarak terbesar dari telah tersimpan, jika suatu waktu akan dicocokkan solusi ideal negatif[7].

dengan informasi atau pedoman yang baru, serta tak lupa Secara umum, prosedur dari metode Topsis meliputi masalah pembuatan laporan yang terlambat terkadang langkah-langkah dibawah ini :

juga menghambat penyampaian informasi.Penyaluran beras (Raskin) lewat tiap-tiap RT, ketua RT yang menentukan berhak dan tidaknya keluarga untuk mendapatkan beras (Raskin).Pengambilan keputusan untuk menentukan kriteria penerima beras yang sudah terjadi biasanya tidak mengacu pada kriteria-kriteria keluarga miskin [3].

Untuk mengatasi masalah tersebut, maka dibutuhkan sebuah kriteria yang nantinya akan diimplementasikan ke sebuah sistem yang dapat membantu pihak kelurahan dalam menentukan penerimaan raskin, agar pemberian beras raskin sesuai dan tepat sasaran. Sistem ini nantinya akan membantu melakukan penilaian pada setiap A_i pada kriteriaC_j yang ternormalisasi dapat

keluarga miskin dan melakukan perubahan kriteria. Hal ini berguna untuk memudahkan pengambil keputusan yang terkait dengan masalah seleksi penerima beras untuk keluarga miskin (Raskin), sehingga akan di dapatkan keluarga yang paling layak diberi raskin.Oleh karena itu, dalam sistem yang akan dibuat nanti untuk keluarga miskin (Raskin) akan menggunakan beberapa kriteria yang diharapkan sesuai dengan kriteria-kriteria keluarga miskin.

Berdasarkan latar belakang diatas, maka dalam penelitian ini penulis mengambil judul "Penerapan Teknik Klasifikasi Dalam Sistem Pendukung Keputusan Penerimaan Raskin Pada Kelurahan Ponorogo Menggunakan Metode Fuzzy Topsis".

\section{Tinjauan Pustaka}

\subsection{Sistem Pendukung Keputusan}

SPK merupakan sebuah proses atau tindakan untuk mencapai suatu tujuan. Spk dapat dikatakan sebagai sistem berbasis komputer dan dapat membantu memecahkan suatu masalah, dengan adanya sistem tersebut mempermudah seseorang untuk memecahkan suatu masalah dengan cepat.[3][4]

\subsection{Program Beras Untuk Rumah Tangga Miskin (raskin)}

Program raskim merupakan salah satu program bantuan pangan untuk mengendalikan kemiskinan dan perlindungan sosial yang diselenggarakan oleh pemerintah pusat dalam bentuk beras bersubsidi kepada rumah tangga berpendapatan rendah (rumah tangga miskin dan rentan miskin) [5].

$$
r_{i j}=\frac{X_{i j}}{\sqrt{\sum_{i=1}^{m} X_{i j}^{2}}}
$$

Dengan $\mathrm{i}=1,2 \ldots, \mathrm{m}$; dan $\mathrm{j}=1,2 \ldots, \mathrm{n}$; dimana $r_{i j}$ adalah matriks ternormalisasi [i][j] sedangkan $X_{i j}$ adalah merupakan matriks keputusan [i][j]. Solusi ideal positif $A^{+}$dan solusi ideal negatif $A^{-}$dapat ditentukan berdasarkan rating bobot ternormalisasi $\left(y_{i j}\right)$ Dapat dilihat pada persamaan (2).

$$
y_{i j}=\text { wi.rij; }
$$

Dengan $\mathrm{i}=1,2 \ldots, \mathrm{m}$; dan $\mathrm{j}=1,2, \ldots, \mathrm{n}$

$$
\begin{aligned}
& \mathrm{A}^{+}=\left(y_{i}^{+}, y_{2}^{+}, \ldots ., y_{n}^{+}\right) ; \\
& \mathrm{A}^{-}=\left(y_{2}^{-}, y_{2}^{-}, \ldots ., y_{n}^{-}\right) ;
\end{aligned}
$$

Dimana y_ij adalah matriks ternormalisasi terbobot [i][j] dan W_i merupakan vektor bobot[i]. Agar dapat menghitung nilai solusi ideal, terlebih dahulu harus menentukan apakah bersifat keuntungan (benefit) atau bersifat biaya (cost). Dimana jika $\mathrm{j}$ adalah atribut keuntungan (benefit) maka $\mathrm{y}_{-} \mathrm{j}^{\wedge}+$ adalah max y_ij dan $y_{-} j^{\wedge}$ - adalah min $y_{-} i j$ sebaliknya jika $j$ adalah atribut biaya (cost) maka $y_{-} j^{\wedge}+$ adalah min $y_{-} i j$ dan $y_{-} j^{\wedge}-$ adalah max y_ij. Jarak antara alternative A_i dengan solusi ideal positif dapat dilihat pada persamaan (3).

$$
D_{i}^{+}=\sqrt{\sum_{i=1}^{n}\left(y_{i}^{+}-y_{i j}\right)^{2}} \quad ;=1,2, \ldots, m(i i i)
$$

\subsection{Fuzzy Topsis}

Logika fuzzy atau sering juga disebut dengan logika Dimana $D_{-} i^{\wedge}+$ adalah jarak alternatif A_i dengan solusi samar dapat di artikan sebagai pemetaan sebuah ruang ideal positif, $\mathrm{y}_{-} \mathrm{i}^{\wedge}+$ merupakan solusi ideal positif [i] dan input menjadi sebuah ruang output yang terdiri dari 
y_ij adalah matriks normalisasi terbobot [i] [j]. Untuk 4. Hasil dan Pembahasan rumus

jarak antara alternative $A_{i}$ dengan solusi ideal Pada bagian ini hasil dan pembahasan dilakukan melalui negatif dapat dilihat pada persamaan (4).

$$
D_{i}^{-}=\sqrt{\sum_{j=1}^{n}\left(y_{i j}-y_{i}^{-}\right)^{2}} \quad(; i=1,2, \ldots, m
$$

\subsection{PHP (Hypertext Preprocessor)}

PHP pada awalnya merupakan singkatan dari Personal Home Page (Situs Personal). PHP pertama kali dibuat oleh Rasmus Lerdorf pada tahun 1995. Pada waktu itu PHP masih bernama Form Interpreted (FI), yang wujudnya berupa sekumpulan skip yang digunakan untuk mengolah data formulir dari web[8].

\subsection{Sistem}

sistem adalah Sekelompok komponen-komponen yang saling berkaitan (subsistem-subsistem yang bersatu untuk mencapai tujuan yang sama) yaitu informasi yang bermanfaat [9].

\section{Metodologi Penelitian}

Metode Penelitian ini menggunakan teknik fuzzy dengan menggunakan metode TOPSIS adapun tahapan pada metode ini adalah seperti pada gambar 1 sebagai berikut.

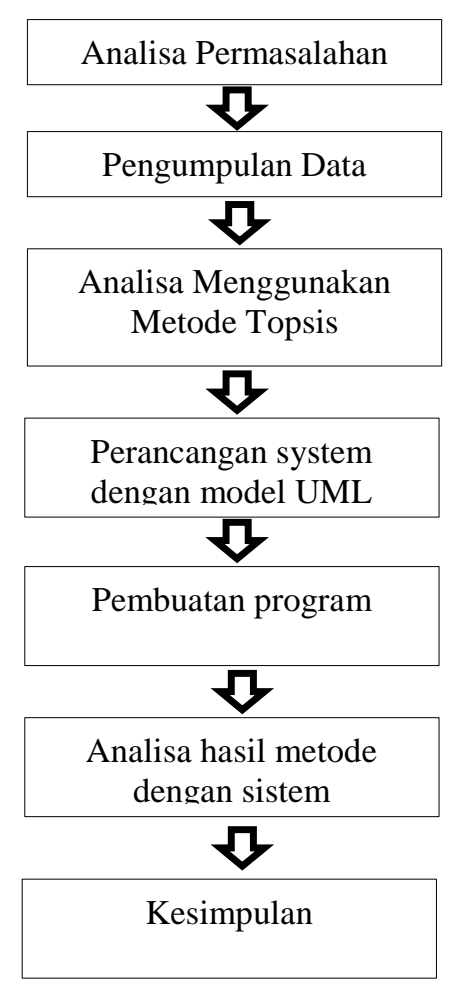

Gambar 1. Metodelogi Penelitian proses perancangan system dengan menggunakan model UML[10], analisa data dilakukan dengan menggunakan metode TOPSIS dan system dibangun menggunakan Bahasa pemrograman php adapun tahapan sebagai berikut.

\subsection{Perancangan Use Case}

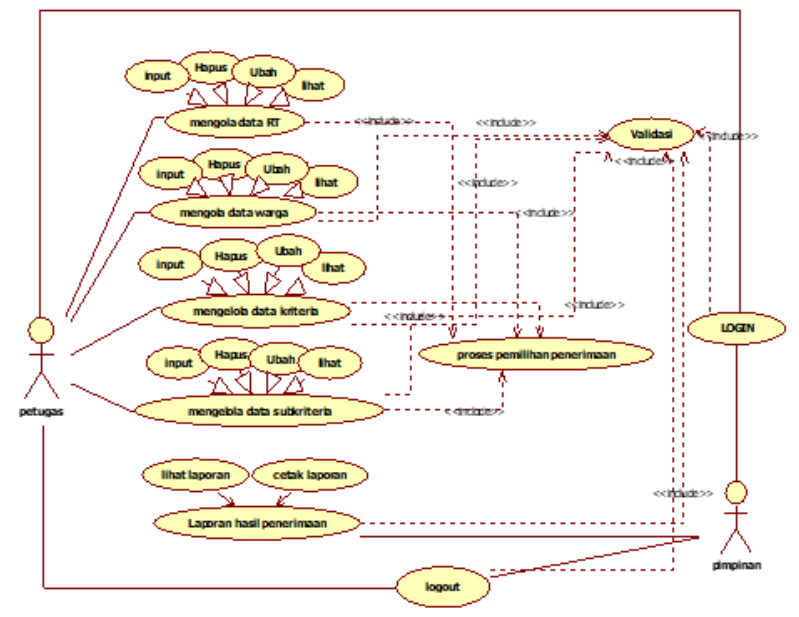

Gambar 2. Perancangan Use Case

\subsection{Class Diagram}

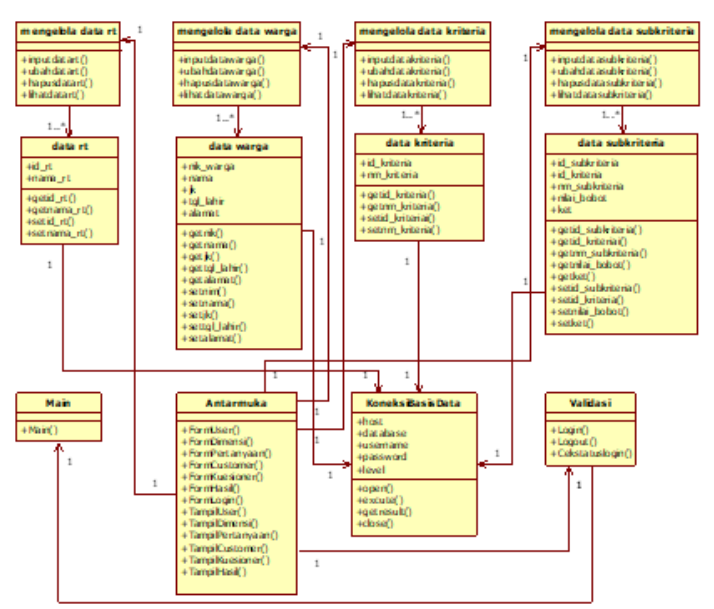

Gambar 3. Class Diagram

\subsection{Perhitungan Fuzzy Topsis}

1) Menentukan matriks keputusan ternormalisasi Untuk menentukan matriks keputusan ternormalisasi nilai dari setiap kriteria dipangkatkan dan dijumlahkan seluruhnya dan hasil dari penjumlahan tersebut diakarkan, kemudian nilai dari setiap kriteria dibagi dengan hasil yang sudah diakarkan tersebut. 
Tabel 1. Hasil Nilai Pembagi dari setiap kriteria Kepemilikan Pekerjaan Penghasilan pendidikan rumah

$\begin{array}{llll}\mathbf{5 , 3 9} & 6,48 & 5,39 & 5,66\end{array}$

Sebelum menentukan matriks keputusan ternormalisasi, sebaiknya mencari nilai pembagi terlebih dahulu, seperti contoh tabel di atas yang sudah mendapat hasilnya. Hasil yang ada pada tabel diatas ialah didapat dari hasil perkalian pada setiap kriteria yang ada. Adapun perhitungannya yaitu.

Kriteria 1 (kepemilikan rumah)

$=\sqrt{(3)^{2}+(3)^{2}+(1)^{2}+(1)^{2}+(3)^{2}}$

$=\sqrt{9+9+1+1+9}$

$=\sqrt{29}=5,39$

Kriteria 2 (pekerjaan)

$=\sqrt{(2)^{2}+(3)^{2}+(4)^{2}+(2)^{2}+(3)^{2}}$

$=\sqrt{4+9+16+4+9}$

$=\sqrt{42}=6,48$

Kriteria 3 (penghasilan)

$=\sqrt{(1)^{2}+(1)^{2}+(3)^{2}+(3)^{2}+(3)^{2}}$

$=\sqrt{1+1+9+9+9}$

$=\sqrt{29}=5,39$

Kriteria 4 (kepemilikan rumah)

$=\sqrt{(2)^{2}+(2)^{2}+(2)^{2}+(2)^{2}+(4)^{2}}$

$=\sqrt{4+4+4+4+16}$

$=\sqrt{32}=5,66$

$$
r_{i j}=\frac{X_{i j}}{\sqrt{\sum_{i=1}^{m} X_{i j}^{2}}}
$$

1. Perhitungan dari kriteria kepemilikan rumah

a) Nama warga Fredy

$=\frac{3}{\mathbf{5 , 3 9}}=0,56$

b) Nama warga Wendo

$=\frac{3}{5,39}=0,56$

c) Nama warga Satria

$$
=\frac{1}{\mathbf{5 , 3 9}}=0,19
$$

d) Nama warga Budisantoso

$$
=\frac{1}{\mathbf{5 , 3 9}}=0,19
$$

f. Nama warga Dhani

$$
=\frac{3}{\mathbf{5 , 3 9}}=0,56
$$

2. Perhitungan dari kriteria pekerjaan

a) Nama warga Fredy

$$
=\frac{2}{\mathbf{6 , 4 8}}=0,31
$$

b) Nama warga Wendo

$$
=\frac{3}{\mathbf{6 , 4 8}}=0,46
$$

c) Nama warga Satria

$$
=\frac{4}{\mathbf{6 , 4 8}}=0,62
$$

d) Nama warga Budisantoso

$$
=\frac{2}{\mathbf{6 , 4 8}}=0,31
$$

e) Nama warga Dhani

$$
=\frac{3}{\mathbf{6 , 4 8}}=0,46
$$

3. Perhitungan dari kriteria penghasilan

a) Nama warga Fredy

$$
=\frac{1}{\mathbf{5 , 3 9}}=0,19
$$

b) Nama warga Wendo

$$
=\frac{1}{\mathbf{5 , 3 9}}=0,19
$$

c) Nama warga Satria

$$
=\frac{3}{\mathbf{5 , 3 9}}=0,56
$$

d) Nama warga Budisantoso

$$
=\frac{3}{\mathbf{5 , 3 9}}=0,56
$$

e) Nama warga Dhani

$$
=\frac{3}{\mathbf{5 , 3 9}}=0,56
$$

4. Perhitungan dari kriteria pendidikan

a) Nama warga Fredy

$$
=\frac{2}{\mathbf{5 , 6 6}}=0,35
$$

b) Nama warga Wendo

$$
=\frac{2}{\mathbf{5 , 6 6}}=0,35
$$

c) Nama warga Satria

$$
=\frac{2}{\mathbf{5 , 6 6}}=0,35
$$

d) Nama warga Budisantoso

$$
=\frac{2}{\mathbf{5 , 6 6}}=0,35
$$

e) Nama warga Dhani

$$
=\frac{4}{\mathbf{5 , 6 6}}=0,71
$$

2) Menentukan matriks solusi ideal positif (+) dan solusi ideal negatif (-)

Untuk menentukan solusi ideal positif (+) dipilih dari nilai yang paling besar dari matrik nilai keputusan ternormalisasi, begitu juga dengan menentukan solusi ideal negatif (-) dipilh dari nilai yang paling kecil dari matrik nilai keputusan ternormalisasi. Dengan demikian dapat ditentukanlah Solusi Ideal Positif (+) dan Solusi Ideal Negatif (-) seperti pada tabel di bawah ini :

Tabel 2. Solusi Ideal Positif (+) dan Solusi Ideal Negatif (-)

\begin{tabular}{|c|r|r|r|r|}
\hline & $\begin{array}{c}\text { Kepemilikan } \\
\text { Rumah }\end{array}$ & Pekerjaan & Penghasilan & Pendidikan \\
\hline $\operatorname{Max}\left(\mathrm{D}^{+}\right)$ & 1,11 & 1,85 & 2,23 & 0,71 \\
\hline $\operatorname{Min}\left(\mathrm{D}^{-}\right)$ & 0,37 & 0,93 & 0,74 & 0,35 \\
\hline
\end{tabular}

3) Menentukan jarak antara nilai dari setiap alternatif dengan solusi ideal positif dan solusi ideal negatif.

$D_{i}^{+}=\sqrt{\sum_{i=1}^{n}\left(y_{i}^{+}-y_{i j}\right)^{2} ;} \quad i=1,2, \ldots, m$

a) Fredy

$D^{+}=\sqrt{\begin{array}{c}(1,11-1,11)^{2}+(1,85-0,93)^{2} \\ +(2,23-0,74)^{2}+(0,71-0,35)^{2}\end{array}}$

Jurnal Ilmiah Binary STMIK Bina Nusantara Jaya

Vol. 01 No. 02 Tahun 2019, ISSN : 2657- 2117 


$$
\mathrm{D}^{=}=\sqrt{\begin{array}{c}
(0,37-1,11)^{2}+(0,93-0,93)^{2} \\
+(0,74-0,74)^{2}+(0,35-0,35)^{2}
\end{array}}
$$

b) Satria

$$
\begin{aligned}
\mathrm{D}^{+} & =\sqrt{\begin{array}{c}
(1,11-1,11)^{2}+(1,85-1,39)^{2} \\
+(2,23-0,74)^{2}+(0,71-0,35)^{2}
\end{array}} \\
& =1,60 \\
\mathrm{D}^{=} & =\sqrt{\begin{array}{c}
(0,37-1,11)^{2}+(0,93-1,39)^{2} \\
+(0,74-0,74)^{2}+(0,35-0,35)^{2}
\end{array}} \\
& =0,88
\end{aligned}
$$

c) Wendo

$$
\begin{aligned}
\mathrm{D}^{+} & =\sqrt{\begin{array}{c}
(1,11-0,37)^{2}+(1,85-1,85)^{2} \\
+(2,23-2,23)^{2}+(0,71-0,35)^{2}
\end{array}} \\
& =0,82 \\
D^{=} & =\sqrt{\begin{array}{c}
(0,37-0,37)^{2}+(0,93-1,85)^{2} \\
+(0,74-2,23)^{2}+(0,35-0,35)^{2}
\end{array}} \\
& =1,75
\end{aligned}
$$

d) Budisantoso

$$
\begin{aligned}
\mathrm{D}^{+} & =\sqrt{\begin{array}{c}
(1,11-0,37)^{2}+(1,85-0,93)^{2} \\
+(2,23-2,23)^{2}+(0,71-0,35)^{2}
\end{array}} \\
& =1,24 \\
\mathrm{D}^{=} & =\sqrt{\begin{array}{c}
(0,37-0,37)^{2}+(0,93-0,93)^{2} \\
+(0,74-2,23)^{2}+(0,35-0,35)^{2}
\end{array}} \\
& =1,49
\end{aligned}
$$

e) Dhani

$$
\begin{aligned}
D^{+} & =\sqrt{\begin{array}{c}
(1,11-1,11)^{2}+(1,85-1,39)^{2} \\
+(2,23-2,23)^{2}+(0,71-0,71)^{2}
\end{array}} \\
& =0,46 \\
& \sqrt{\begin{array}{c}
(0,37-1,11)^{2}+(0,93-1,39)^{2} \\
+(0,74-2,23)^{2}+(0,35-0,71)^{2}
\end{array}} \\
& =1,76
\end{aligned}
$$

Tabel 3. Jarak Solusi Ideal Positif dan Solusi Ideal Negatif

\begin{tabular}{ccc}
\hline Nama & $\mathrm{D}^{+}$ & $\mathrm{D}^{-}$ \\
\hline Fredy & 1,79 & 0,74 \\
\hline Wendo & 1,60 & 0,88 \\
\hline Satria & 0,82 & 1,75 \\
\hline Budisantoso & 1,24 & 1,49 \\
\hline Dhani & 0,46 & 1,76 \\
\hline
\end{tabular}

4) Menentukan nilai preferensi untuk setiap alternatif

a) Nilai Preferensi Alternatif Fredy

$$
\begin{aligned}
& \frac{D_{i}^{-}}{D_{i}^{-}+D_{i}^{+}} \\
& =\frac{0,74}{0,74+1,79} \\
& =\mathbf{0 , 2 9}
\end{aligned}
$$

b) Nilai Preferensi Alternatif Wendo

$$
\begin{aligned}
& \frac{D_{i}^{-}}{D_{i}^{-}+D_{i}^{+}} \\
& =\frac{0,88}{0,88+1,60} \\
& =\mathbf{0 , 3 5}
\end{aligned}
$$

c) Nilai Preferensi Alternatif Satria

$$
\begin{aligned}
& \frac{D_{i}^{-}}{D_{i}^{-}+D_{i}^{+}} \\
& =\frac{1,75}{1,75+0,82} \\
& =\mathbf{0 , 6 8}
\end{aligned}
$$

d) Nilai Preferensi Alternatif Budisantoso

$$
\begin{aligned}
& \frac{D_{i}^{-}}{D_{i}^{-}+D_{i}^{+}} \\
& =\frac{1,49}{1,49+1,24} \\
& =\mathbf{0}, \mathbf{5 5}
\end{aligned}
$$

e) Nilai Preferensi Alternatif Dhani

$$
\begin{aligned}
& \frac{D_{i}^{-}}{D_{i}^{-}+D_{i}^{+}} \\
& =\frac{1,76}{1,76+0,46} \\
& =\mathbf{0 , 7 9}
\end{aligned}
$$

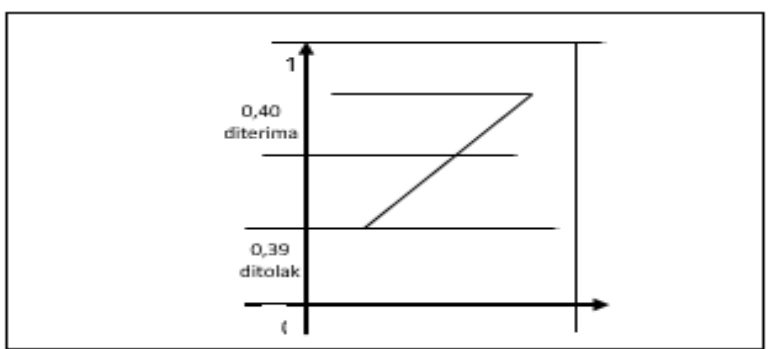

Gambar 4. Kurva Fuzzy

Pada gambar diatas menunjukkan nilai dari setiap alternatif yang sudah di hitung. Nilai yang terdapat pada kurva di atas dimulai dari 0.40 sampai 1 dengan status "Layak", sedangkan 0 sampai 0.39 dengan status "ditolak". Adapun tabel dibawah ini mengenai nilai dari refrensi setiap alternatif .

Tabel 4. Nilai Refrensi Setiap Alternatif

\begin{tabular}{cc}
\hline Nama & Nilai Refrensi \\
\hline Fredy & 0,29 \\
\hline Wendo & 0,35 \\
\hline Satria & 0,68
\end{tabular}




\begin{tabular}{cc}
\hline Budisansoto & 0,55 \\
\hline Dhani & 0,79 \\
\hline Dari perhitungan diatas pada table diatas diketahui nilai
\end{tabular}

Dari perhitungan diatas pada table diatas diketahui nilai yang memenuhi nilai minimal diterima oleh Fredy dan Wendo yang layak direkomendasikan menjadi penerima raskin.

\subsection{Implementasi Sistem}

\section{1) Perhitungan Hasil Penerimaan Raskin}

Pada halaman ini, data warga yang sudah di proses di halaman data warga calon penerima raskin dimana data-data tersebut akan menampilkan hasil hasil hitung yang menggunakan metode fuzzy topsis.

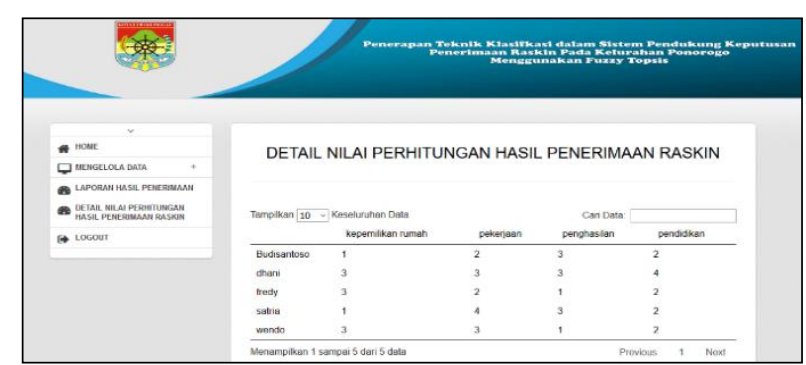

Gambar 5. Halaman Detail Nilai Perhitungan Hasil Penerimaan Raskin

Dibawah ini terdapat tabel perbandingan, yang contohnya di ambil dari salah satu cara penyelesaian metode topsis :

Tabel 5. Tabel Perbandingan

\begin{tabular}{llrl}
\hline Nama & \multicolumn{1}{c}{ Manual } & Sistem & \multicolumn{1}{c}{ Ket } \\
\hline Fredy & $=\frac{0,74}{0,74+1,79}$ & $\mathbf{0 , 2 9}$ & $\begin{array}{l}\text { Pada perhitungan } \\
\text { manual, perlu dihitung } \\
\text { satu persatu, sedangkan } \\
\text { perhitungan sistem akan } \\
\text { langsung menampilkan } \\
\text { hasil ketika user meng- } \\
\text { inputkan data ke sistem }\end{array}$ \\
Wendo & $=\frac{0,88}{0,88+1,60}$ & $\mathbf{0 , 3 5}$ & \\
& $=\mathbf{0 , 3 5}$ & $\mathbf{0 , 6 8}$ & \\
Satria & $=\frac{1,75}{1,75+0,82}$ & $\mathbf{0 , 6 8}$ &
\end{tabular}

2) laporan data calon penerima raskin merupakan laporan berupa data calon penerima raskin yang digunakan untuk menampilkan semua data calon penerima raskin yang telah di inputkan

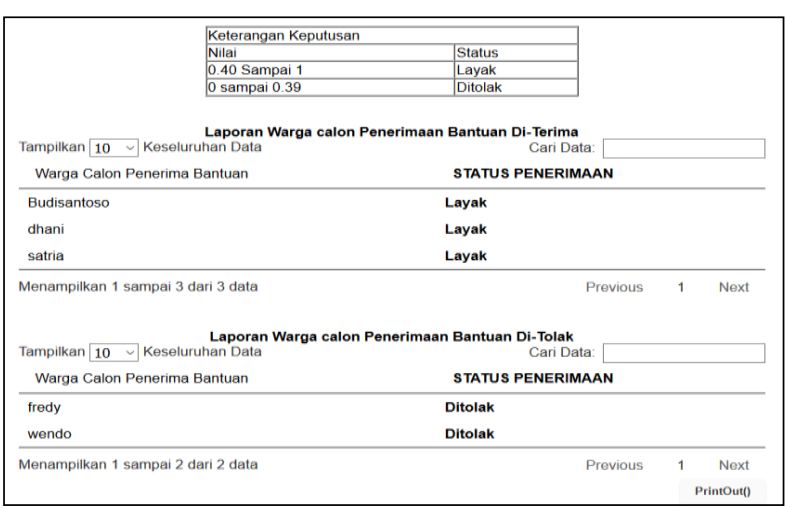

Gambar 6. Halaman Laporan Hasil Penerimaan Raskin

\section{Kesimpulan}

5.1. Kesimpulan

Dari hasil penelitian tentang penerapan metode simple Dari hasil penelitian tentang Penerapan Teknik Klasifikasi Dalam Sistem Pendukung Keputusan Penerimaan Raskin Pada Kelurahan Ponorogo Menggunakan Fuzzy Topsis, maka dapat ditarik kesimpulan, yaitu :

1. Kriteria - kriteria yang digunakan dalam melakukan proses seleksi kelayakan calon penerima raskin di kelurahan ponorogo adalah sebagai berikut :

1) Penghasilan, untuk mengetahui pendapatan dari setiap warga

2) Pekerjaan, untuk mengetahui pekerjaan yang setiap warga

3) Kepemilikan rumah, untu mengetahui status rumah dari setiap warga

4) Pendidikan, digunakan untuk mengetahui pendidikan terakhir setiap warga

2. Menghasilkan sebuah Sistem Pendukung Keputusan untuk Penerapan Teknik Klasifikasi Dalam Sistem Pendukung Keputusan Penerimaan Raskin Pada Kelurahan Ponorogo yang dapat mengatasi masalah dalam menentukan penerima raskin. Sistem Pendukung Keputusan ini juga akan menghasilkan nilai akhir dari proses perhitungan yang nantinya digunakan untuk memudahan pengambil keputusan dalam menentukan warga yang layak mendapat bantuan tersebut.

3. Menghasilkan sebuah Sistem Pendukung Keputusan untuk menyeleksi calon penerima bantuan raskin mengguanakan metode fuzzy topsis, dimana metode ini akan menghitung nilai setiap kriteria dari setiap alternatif, yang kemudian akan menghasilkan nilai akhir.

\subsection{Saran}

Sistem pendukung keputusan untuk penerima raskin di kelurahan ponorogo menggunakan metode fuzzy topsis ini tentu masih memiliki banyak kekurangan, oleh sebab itu penulis berharap sistem ini dapat 
dikembangkan lebih lanjut. Untuk itu, adapun saran yang penulis memberikan sebagai berikut :

1. Metode fuzzy topsis bukanlah satu-satunya metode yang dapat digunakan dalam penentuan penerimaan raskin, oleh karena itu diharapkan pada penelitian selanjutnya dapat membandingkan dari hasil penelitian yang telah dilakukan dengan menggunakan metode yang berbeda pada penelitian yang sama atau sejenis.

2. Untuk penggunaan jangka panjang, diperlukan pengembangan atau update setiap kriteria yang digunakan, jika terdapat perubahan dalam kriteria penerima raskin untuk menyeleksi calon penerima raskin pada kelurahan ponorogo.

\section{Daftar Rujukan}

[1] Maharani, Puan. 2017.Pedoman Umum Bantuan Pangan Non Tunai.Jakarta

[2] Widiarto, Alif, Iman Surya, Burhanuddin. 2018. Efektivitas Program Beras Raskin (Raskin) Dalam Meningkatkan Kesejahteraan Masyarakat Di Desa Tempakan Kecamatan Batu Engau Kebupaten Paser ISSN 2337-8670

[3] Dewi, C, Yeremia, dan Yulianto. 2018. Sistem Penyeleksi Bantuan Beras Miskin Kauman Kidul Menggunakan Metode Weighted Product Berbasis Mobile Jurnal TEKNOIF ISSN 2443-2210.

[4] Ernawati, Aeni, Nur., \& Fetrina, F., 2017, Rancang Bangun Sistem Pendukung Keputusan Kenaikan Jabatan Pegawai dengan Metode Profile Matching. (Studi Kasus: Kementerian Agama Kantor Wilayah DKI Jakarta (Jurnal Sistem Informasi), No. 2 Vol. 10 ISSN:127-134, Halaman $1-8$

[5] Maharani, Puan. 2016. Pedoman Umum Subsidi Beras Bagi Masyarakat Berpendapatan Rendah.Jakarta

[6] Nugraha, Heriada, Septya Maharani, Dyna Marisa Khairina. 2015. Sistem Pendukung Keputusan Rekomendasi Pemilihan Bank untuk Pembukaan Rekening bagi Calon Nasabah menggunakan Metode Topsis ISBN : 978-602-72658-0-6

[7] A. S Rosa dan Shalahuddin, M., 2018, Rekayasa Perangkat Lunak, Buku:Bandun

[8] Yanto, R., 2016, Manajemen Basis Data ... Menggunakan MySQL, Deepublish, Yogyakarta

[9] Machmud, R., 2016, Peranan Penerapan Sistem Informasi Manajemen Terhadapa Efektivitas Kerja Pegawai Lembaga Pemasyarakatan Narkotika (Lapastika) Bollangi Kabupaten Gowa. (Jurnal Capacity Stie Amkop Makassar), No. 3 Vol. 9 ISSN:1907-3311, Halaman 1-13.

[10] Rosa, A.S. dan M. Shalahuddin., 2013, Rekayasa Perangkat Lunak, Informatika, Bandung 